\title{
Synthesis, Characterization and Biological Activity of Symmetric Dinuclear Complexes Derived from a Novel Macrocyclic Compartmental Ligand
}

\author{
B.H.M. Mruthyunjayaswamy*, Omkar B. Ijare and Y. Jadegoud \\ Department of Chemistry, Gulbarga University Gulbarga-585 106, India
}

\begin{abstract}
Um novo ligante macrocíclico binucleador, $N, N$-bis(2,6-diiminometil-1hidroxifenil)malonoildicarboxamida, foi preparado. Seus complexos metálicos foram preparados pelo método da moldagem por metal, através das reações de 2,6-diformil-4-metilfenol, malonoil diidrazida com os cloretos metálicos de $\mathrm{Cu}$ (II), Ni(II), Co(II), Cd(II), Zn(II) e Hg(II), em methanol, que levaram à formação de uma série de complexos dinucleares. Os complexos foram caracterizados por análises elementares, medidas de conductividade, dados de susceptibilidade magnética, IR, UVVis, EPR, RMN e dados de espectrometrica de massas-FAB. A natureza dinuclear dos complexos foi confirmada pelas análises elementares e dados de susceptibilidade magnética, EPR e de espectrometria de massas-FAB. O ligante e os complexos de $\mathrm{Cu}$ (II), Ni(II), Co(II) e Zn(II) tiveram suas atividades antibacteriana e antifúngica testadas contra Escherichia coli, Staphyloccocus aureus, Aspergillus niger e Fusarium oxysporum. As medidas de susceptibilidade magnética dos complexos de $\mathrm{Cu}$ (II), $\mathrm{Ni}$ (II) e $\mathrm{Co}(\mathrm{II})$ revelaram que estes complexos exibem acoplamento antiferromagnético devido à presença de dois íons metálicos próximos um do outro. O espectro de massas-FAB do complexo de $\mathrm{Cu}(\mathrm{II})$ forneceu evidencia clara da sua natureza dinuclear. O ligante e os complexos exibiram atividade muito fraca contra as bactérias testadas, entretanto, o ligante mostrou-se ativo contra o fungo Fusarium oxysporum.
\end{abstract}

A phenol based novel macrocyclic binucleating compartmental ligand $N, N$-bis(2,6-diiminomethyl4-methyl-1-hydroxyphenyl)malonoyldicarboxamide was prepared. The complexes were prepared by template method by reacting 2,6-diformyl-4-methylphenol, malonoyl dihydrazide and the metal chlorides of $\mathrm{Cu}(\mathrm{II}), \mathrm{Ni}(\mathrm{II}), \mathrm{Co}(\mathrm{II}), \mathrm{Cd}(\mathrm{II}), \mathrm{Zn}$ (II) and $\mathrm{Hg}$ (II) in methanol to get a series of dinuclear complexes. The complexes were characterized by elemental analyses, conductivity measurements, magnetic susceptibility data, IR, UV-Vis, ESR, NMR and FAB mass spectral data. The dinuclear nature of the complexes was confirmed on the basis of elemental analyses, magnetic susceptibility, ESR and FAB mass spectral data. The ligand as well as $\mathrm{Cu}$ (II), Ni(II), $\mathrm{Co}$ (II) and $\mathrm{Zn}$ (II) complexes were tested for their antibacterial and antifungal properties against Escherichia coli, Staphyloccocus aureus, Aspergillus niger and Fusarium oxysporum. Magnetic susceptibility measurements of $\mathrm{Cu}(\mathrm{II}), \mathrm{Ni}$ (II) and $\mathrm{Co}$ (II) complexes reveal that these complexes exhibit antiferromagnetic coupling behavior due to the presence of two metal ions in close proximity. FAB mass spectrum of the $\mathrm{Cu}$ (II) complex gave a clear evidence for the dinuclear nature. The ligand and the complexes were found to be less active against the tested bacteria, but the ligand alone was found active against the fungus Fusarium oxysporum.

Keywords: 'macrocyclic' compartmental ligand, dinuclear complexes, 2,6-diformyl-4methylphenol, malonoyl dihydrazide

\section{Introduction}

Efforts have been made in the last decades to the design and synthesis of macrocyclic or macroacyclic complexes and to study their physico-chemical properties. ${ }^{1,2}$ These investigations emphasized the great relevance of these systems in basic and applied chemistry. Several synthetic

* e-mail: bhmmswamy53@rediffmail.com strategies are now a days available for the preparation of well organized molecular systems or molecular devices, which exhibit peculiar physico-chemical properties or have well defined properties. ${ }^{1-4}$ Many macrocyclic or macroacyclic systems containing an appropriate set of donor atoms and a suitable structural configuration are capable of producing new macromolecules which have been used in numerous chemical processes and technologies. Based on this concept many macrocyclic 
systems are available and are already applied in the fields of activation and catalysis, molecular materials, microelectronics, sensors, and so on. ${ }^{4}$ Bimetallic cores have been recognized at the active sites of many metalloenzymes. ${ }^{5}$ Studies on the geometry around the metal by electronic spectra and magnetic properties of the metal ions present in the active sites of the metalloenzymes are rather difficult owing to the fact that the metal ions in active sites are embedded in protein polymer back bone. ${ }^{6}$ Hence, design and synthesis of model compounds that mimic the physical and chemical properties of the active sites present in metalloenzymes is very essential and the studies on such compounds is becoming increasingly important in understanding biological functions of the bimetallic cores. ${ }^{5}$ Dinuclear complexes with two metal ions in close proximity show interesting magnetic, catalytic and electron transfer properties. Efforts to synthesize ligands capable of generating such dinuclear complexes have resulted in a large number of dinuclear ligands. ${ }^{7}$ One of such ligand systems was obtained from " $2+2$ " condensation of 2,6-diformyl-4-methylphenol with 1,3diaminopropane. ${ }^{8}$ Macrocyclic ligands derived by template condensation of 2,6-diformyl-4-methylphenol with simple diamines such as 1,2-ethylenediamine, 1,3propanediamine, 1,4-butanediamine etc., generally produce 2:2 macrocyclic rings, encompassing two metal atoms, bridged by two phenoxide groups and each bound terminally by two imine nitrogen donors. Such complexes particularly in the case of copper are strongly antiferromagnetically coupled and exhibit well-defined one electron redox processes. ${ }^{9}$ A literature survey reveals that, for the synthesis of macrocyclic dinuclear complexes, the ligands employed were generally synthesized by the template condensation of 2,6-diformyl-4-methylphenol with various diamines. There are only a few references wherein the 2,6-diformyl-4-methylphenol has been condensed with aroyl hydrazones, ${ }^{4,10}$ but there are no reports on the complexes of macrocycles obtained by the reaction of 2,6diformyl-4-methylphenol with dicarboxylic acid dihydrazides. In view of these observations, we report here the synthesis, characterization and biological activity of a novel macrocyclic ligand obtained by " $2+2$ " condensation of 2,6-diformyl-4-methylphenol with malonoyl dihydrazide and its dinuclear complexes.

\section{Experimental}

\section{Materials}

All chemicals used were of reagent grade. Solvents were distilled and dried before use according to standard procedures. $^{11}$ 2,6-Diformyl-4-methylphenol ${ }^{12}$ and malonoyl dihydrazide ${ }^{13}$ were prepared by the literature methods. The metal salts used were generally in their hydrated form.

\section{Methods}

Elemental analyses for $\mathrm{C}, \mathrm{H}$, and $\mathrm{N}$ were obtained from Heraeus CHN-O rapid analyzer, IR spectra were recorded on Perkin-Elmer 1000 IR spectrometer using KBr pellets. Conductance measurements were carried out in DMF solution $\left(1 \times 10^{-3} \mathrm{~mol} \mathrm{dm}^{-3}\right)$ using an Elico-CM 82 conductivity bridge. Electronic spectral measurements were carried out using Elico SL 159 spectrophotometer in the range 200-1000 nm. ${ }^{1} \mathrm{H}$ NMR spectra were recorded on Bruker AMX $400 \mathrm{MHz}$ spectrometer, ESR spectrum of $\mathrm{Cu}$ (II) complex was recorded on X-band ESR spectrometer (Varian Associates). Magnetic measurements were made on a Cahn 2000 electro balance by Faraday Method using $\mathrm{Hg}\left[\mathrm{Co}(\mathrm{SCN})_{4}\right]$ as calibrant. FAB mass spectrum of $\mathrm{Cu}(\mathrm{II})$ complex was recorded on a JEOL SX 102/DA-6000 mass spectrometer using Argon/Xenon as the FAB gas.

\section{Preparation of ligand $\mathrm{H}_{2} \mathrm{~L}$}

The ligand was prepared by refluxing 2,6-diformyl-4methylphenol $\left(0.33 \mathrm{~mol} \mathrm{dm}^{-3}\right)$ with malonoyl dihydrazide $\left(0.33 \mathrm{~mol} \mathrm{dm}^{-3}\right)$ in methanol for $5 \mathrm{~h}$. The pale yellow amorphous solid obtained was filtered, washed with little amount of hot methanol $\left(5 \mathrm{~cm}^{3}\right)$ and dried in vacuo (mp $270{ }^{\circ} \mathrm{C}$, yield $68 \%$ ).

\section{Preparation of the complexes}

$\mathrm{Cu}(\mathrm{II}), \mathrm{Ni}$ (II), $\mathrm{Co}$ (II), $\mathrm{Zn}$ (II), $\mathrm{Cd}$ (II) and $\mathrm{Hg}$ (II) complexes of ligand, $\mathrm{H}_{2} \mathrm{~L}$, were prepared adapting template method owing to the insolubility of the ligand in common organic solvents. 2,6-diformyl-4-methylphenol $\left(0.33 \mathrm{~mol} \mathrm{dm}^{-3}\right)$, malonoyl dihydrazide $\left(0.33 \mathrm{~mol} \mathrm{dm}^{-3}\right)$ and respective metal chloride $\left(0.33 \mathrm{~mol} \mathrm{dm}^{-3}\right)$ in methanol were refluxed for 5 $6 \mathrm{~h}$. The separated complexes were collected by filtration, washed with hot methanol and dried under vacuum over $\mathrm{CaCl}_{2}$ (yield $58-75 \%$ ).

\section{Biological activity}

The in vitro biological screening of the ligand $\mathrm{H}_{2} \mathrm{~L}$ and its $\mathrm{Cu}(\mathrm{II}), \mathrm{Ni}(\mathrm{II}), \mathrm{Co}(\mathrm{II})$ and $\mathrm{Zn}(\mathrm{II})$ complexes was undertaken against the bacteria Escherichia coli and Staphyloccocus aureus by the cup-plate method using nutrient agar as medium. In a typical procedure, molten 
nutrient agar kept at $45{ }^{\circ} \mathrm{C}$ was then poured into Petri dishes and allowed to solidify. Then holes of $6 \mathrm{~mm}$ diameter were punched carefully using a sterile cork borer and these were completely filled with test solutions $\left(1000 \mu \mathrm{g} \mathrm{cm}^{-3}\right.$ in DMF). The plates were incubated for $24 \mathrm{~h}$ at $37{ }^{\circ} \mathrm{C}$. The diameter of the zones of inhibition for all the test compounds was measured and the results were compared with the standard drug Ciprofloxacin of the same concentration as that of the test compound under identical conditions.

The antifungal activity of the test compounds was evaluated against the Aspergillus niger and Fusarium oxysporum by cup-plate method cultured on potato-dextrose agar medium adapting similar procedure described above. The plates were incubated at $37^{\circ} \mathrm{C}$ for $48 \mathrm{~h}$. The diameters of the zone of inhibition for all the test compounds were measured and the results were compared with the standard drug Griseofulvin of the same concentration as that of the test compound under identical conditions.

Since all test compounds and standard drugs were prepared in freshly distilled DMF, its zone of inhibition was found to be very negligible and taken as zero $\mathrm{mm}$.

\section{Results and Discussion}

All the complexes were sparingly soluble in common organic solvents but soluble in DMF, DMSO, and acetonitrile. The analytical data (Table 1) indicate that the complexes are dinuclear in nature. The molar conductance (Table 1) values measured in DMF solution $\left(1 \times 10^{-3} \mathrm{~mol}\right.$ $\mathrm{dm}^{-3}$ ) fall in the range $50-62 \mathrm{ohm}^{-1} \mathrm{~cm}^{2} \mathrm{~mol}^{-1}$. These observed values of the molar conductance are well within the expected range for non-electrolytes. ${ }^{14}$

\section{IR spectra}

The important bands in the IR spectra of the ligand as well as complexes together with their assignments are listed in Table 2. The free ligand showed a broad band at 3432 $\mathrm{cm}^{-1}$ due to $v_{\mathrm{OH}}$ in case of ligand has disappeared in all the complexes indicating its involvement in the coordination with the metal ions via deprotonation. ${ }^{15}$ The free ligand showed a medium intensity band at $3210 \mathrm{~cm}^{-1}$ assigned to $v_{\mathrm{NH}}$ vibrations, ${ }^{16}$ which has been observed in the 3203 $3207 \mathrm{~cm}^{-1}$ region in the case of the complexes. It can be observed that there is no considerable shift in the $v_{\mathrm{NH}}$ vibrations in the case of the complexes compared to the ligand, indicates non-involvement of amide $\mathrm{NH}$ function in the coordination. A strong intensity band observed at $1675 \mathrm{~cm}^{-1}$ and a medium intensity band at $1630 \mathrm{~cm}^{-1}$ in the case of the ligand are assigned to $v_{\mathrm{C}=\mathrm{O}}$ and $v_{\mathrm{C}=\mathrm{N}}$ functions respectively. In the case of complexes the band due to $v_{\mathrm{C}=\mathrm{O}}$ was observed in the $1670-1676 \mathrm{~cm}^{-1}$ region, indicating its non-involvement in the complexation. ${ }^{17}$ The band due to $v_{\mathrm{C}=\mathrm{N}}$ observed at $1630 \mathrm{~cm}^{-1}$ in the case of the ligand has shown a negative shift of $14-3 \mathrm{~cm}^{-1}$ in the complexes which suggests the involvement of azomethine group $(\mathrm{C}=\mathrm{N})$ in the coordination with the metal ions and bonded through the nitrogen atom. ${ }^{18}$ The band due to phenolic C-O observed at $1240 \mathrm{~cm}^{-1}$ in the case of the ligand has shifted towards higher wave number and this positive shift of the band suggests the coordination of the phenolate anions with the metal ions via deprotonation. ${ }^{15}$ Further, the appearance of new bands in the 1536-1555 $\mathrm{cm}^{-1}$ region in all the complexes suggest phenoxide bridging with the metal ions. ${ }^{19}$ The presence of broad stretching vibrations in the $3444-3401 \mathrm{~cm}^{-1}$ region can be

Table 1. Physical, analytical, magnetic susceptibility and molar conductivity data of Ligand $\mathrm{H}_{2} \mathrm{~L}$ and its complexes

\begin{tabular}{|c|c|c|c|c|c|c|c|c|c|c|}
\hline \multirow{2}{*}{$\begin{array}{l}\text { Ligand/ } \\
\text { Complex }\end{array}$} & \multirow{2}{*}{$\begin{array}{l}\text { Empirical } \\
\text { Formula }\end{array}$} & \multirow{2}{*}{$\begin{array}{l}\text { Mol.Wt. \% } \\
\text { (Colour) }\end{array}$} & \multirow{2}{*}{$\begin{array}{c}\mathrm{mp} /{ }^{\circ} \mathrm{C} \\
\text { (yield / (\%)) }\end{array}$} & \multicolumn{5}{|c|}{ Elemental analysis (\%): Found (Calc.) } & \multirow{2}{*}{$\begin{array}{c}\mu_{\text {eff }} \\
(\text { B.M) }\end{array}$} & \multirow{2}{*}{$\begin{array}{l}\lambda_{\mathrm{M}} \\
(\mathrm{S})\end{array}$} \\
\hline & & & & $\mathrm{M}$ & $\mathrm{C}$ & $\mathrm{H}$ & $\mathrm{N}$ & $\mathrm{Cl}$ & & \\
\hline $\mathrm{H}_{2} \mathrm{~L}$ & $\mathrm{C}_{24} \mathrm{H}_{24} \mathrm{~N}_{8} \mathrm{O}_{6}$ & $\begin{array}{c}520 \\
\text { (Yellow) }\end{array}$ & $\begin{array}{l}270 \\
(70)\end{array}$ & - & $\begin{array}{c}55.32 \\
(55.38)\end{array}$ & $\begin{array}{c}4.60 \\
(4.62)\end{array}$ & $\begin{array}{c}21.56 \\
(21.53)\end{array}$ & - & - & - \\
\hline $\mathrm{Cu}$-comp. & $\mathrm{Cu}_{2}\left[\mathrm{LCl}_{2}\right] \cdot 3 \mathrm{H}_{2} \mathrm{O}$ & $\begin{array}{c}770.08 \\
\text { (Brown) }\end{array}$ & $\begin{array}{c}>300 \\
(68)\end{array}$ & $\begin{array}{c}16.46 \\
(16.50)\end{array}$ & $\begin{array}{c}37.42 \\
(37.39)\end{array}$ & $\begin{array}{c}3.65 \\
(3.63)\end{array}$ & $\begin{array}{c}14.51 \\
(14.54)\end{array}$ & $\begin{array}{c}9.20 \\
(9.21)\end{array}$ & 1.42 & 60 \\
\hline Ni-comp. & $\mathrm{Ni}_{2}\left[\mathrm{LCl}_{2}\left(\mathrm{H}_{2} \mathrm{O}\right)_{2}\right] \cdot \mathrm{H}_{2} \mathrm{O}$ & $\begin{array}{l}742.38 \\
\text { (Brown) }\end{array}$ & $\begin{array}{c}>300 \\
(62)\end{array}$ & $\begin{array}{c}15.84 \\
(15.81)\end{array}$ & $\begin{array}{c}38.77 \\
(38.79)\end{array}$ & $\begin{array}{c}3.45 \\
(3.50)\end{array}$ & $\begin{array}{c}15.11 \\
(15.08)\end{array}$ & $\begin{array}{c}9.50 \\
(9.56)\end{array}$ & 2.77 & 58 \\
\hline Co-comp. & $\mathrm{Co}_{2}\left[\mathrm{LCl}_{2}\right] \cdot 2 \mathrm{H}_{2} \mathrm{O}$ & $\begin{array}{c}742.86 \\
\text { (Brown) }\end{array}$ & $\begin{array}{c}>300 \\
(63)\end{array}$ & $\begin{array}{c}15.78 \\
(15.86)\end{array}$ & $\begin{array}{c}38.75 \\
(38.76)\end{array}$ & $\begin{array}{c}3.50 \\
(3.49)\end{array}$ & $\begin{array}{c}15.10 \\
(15.07)\end{array}$ & $\begin{array}{c}9.53 \\
(9.55)\end{array}$ & 4.21 & 61 \\
\hline Zn-comp. & $\mathrm{Zn}_{2}\left[\mathrm{LCl}_{2}\right] \cdot 2 \mathrm{H}_{2} \mathrm{O}$ & $\begin{array}{c}755.78 \\
\text { (Yellow) }\end{array}$ & $\begin{array}{l}247 \\
(58)\end{array}$ & $\begin{array}{c}17.39 \\
(17.30)\end{array}$ & $\begin{array}{c}38.11 \\
(38.10)\end{array}$ & $\begin{array}{c}3.42 \\
(3.44)\end{array}$ & $\begin{array}{c}14.80 \\
(14.81)\end{array}$ & $\begin{array}{c}9.36 \\
(9.39)\end{array}$ & dia* $^{*}$ & 53 \\
\hline Cd-comp. & $\mathrm{Cd}_{2}\left[\mathrm{LCl}_{2}\right] \cdot 2 \mathrm{H}_{2} \mathrm{O}$ & $\begin{array}{c}849.82 \\
\text { (Yellow) }\end{array}$ & $\begin{array}{l}283 \\
(75)\end{array}$ & $\begin{array}{c}26.38 \\
(26.45)\end{array}$ & $\begin{array}{c}33.85 \\
(33.88)\end{array}$ & $\begin{array}{c}3.10 \\
(3.05)\end{array}$ & $\begin{array}{c}13.21 \\
(13.17)\end{array}$ & $\begin{array}{c}8.38 \\
(8.35)\end{array}$ & dia* & 62 \\
\hline $\mathrm{Hg}$-comp. & $\mathrm{Hg}_{2}\left[\mathrm{LCl}_{2}\right] \cdot 2 \mathrm{H}_{2} \mathrm{O}$ & $\begin{array}{c}1026.1 \\
\text { (Yellow) }\end{array}$ & $\begin{array}{l}268 \\
(64)\end{array}$ & $\begin{array}{c}39.67 \\
(39.09)\end{array}$ & $\begin{array}{c}28.04 \\
(28.06)\end{array}$ & $\begin{array}{c}2.51 \\
(2.53)\end{array}$ & $\begin{array}{c}10.90 \\
(10.91)\end{array}$ & $\begin{array}{c}6.93 \\
(6.91)\end{array}$ & dia* & 50 \\
\hline
\end{tabular}

*Diamagnetic, $\mathrm{S}-\mathrm{ohm}^{-1} \mathrm{~cm}^{2} \mathrm{~mol}^{-1}$. 
Table 2. IR spectral assignments of the ligand $\mathrm{H}_{2} \mathrm{~L}$ and its complexes

\begin{tabular}{lcccccccc}
\hline Ligand/Complex & $v_{\mathrm{OH}} / v_{\mathrm{H}_{2} \mathrm{O}}$ & $v_{\mathrm{NH}}$ & $v_{\mathrm{CH}_{3}}$ & $v_{\mathrm{C}=\mathrm{O}}$ & $v_{\mathrm{C}=\mathrm{N}}$ & Phenolic $v_{\mathrm{C}-\mathrm{O}}$ & $v_{\mathrm{M}-\mathrm{O}}$ & $v_{\mathrm{M}-\mathrm{N}}$ \\
\hline $\mathrm{H}_{2} \mathrm{~L}$ & 3432 & 3210 & 2919 & 1675 & 1630 & 1240 & - & - \\
Cu-comp. & 3427 & 3203 & 2919 & 1674 & 1627 & 1540 & 515 & 464 \\
Ni-comp. & 3427 & 3207 & 2920 & 1672 & 1618 & 1536 & 571 & 466 \\
Co-comp. & 3401 & 3203 & 2906 & 1670 & 1626 & 1550 & 579 & 479 \\
Zn-comp. & 3412 & 3203 & 2920 & 1676 & 1616 & 1548 & 568 & 476 \\
Cd-comp. & 3444 & 3207 & 2920 & 1674 & 1627 & 1555 & 568 & 417 \\
Hg-comp. & 3417 & 3205 & 2920 & 1674 & 1620 & 1552 & 568 & 417 \\
\hline
\end{tabular}

attributed to coordinated or lattice water molecules in all the complexes. ${ }^{15}$ The low frequency skeletal vibrations due to $\mathrm{M}-\mathrm{O}$ and $\mathrm{M}-\mathrm{N}$ stretching provide direct evidence for the complexation. In the present investigation, the bands in the $579-515 \mathrm{~cm}^{-1}$ region have been assigned to $v_{\mathrm{M}-\mathrm{O}}$ and the bands observed in the $479-417 \mathrm{~cm}^{-1}$ region for $v_{\mathrm{M}-\mathrm{N}}$ vibrations respectively. ${ }^{20,21}$ The bands due to $v_{\mathrm{M}-\mathrm{Cl}}$ were observed in the $339-313 \mathrm{~cm}^{-1}$ region and are characteristic of chloro-bridged binuclear complexes. ${ }^{22}$

\section{Magnetic susceptibility}

The room temperature magnetic susceptibility values are recorded in Table 1. $\mathrm{Cu}$ (II) complex of ligand $\mathrm{H}_{2} \mathrm{~L}$ showed a magnetic moment of 1.42 B.M. which is considerably lower than the spin only value for $\mathrm{Cu}$ (II) complexes. The low value of the magnetic moment is attributed for the antiferromagnetic coupling interaction between two metal ions. This fact suggests the dinuclear nature of the $\mathrm{Cu}$ (II) complex. ${ }^{23}$ On the other hand, $\mathrm{Ni}$ (II) and $\mathrm{Co}(\mathrm{II})$ complexes have shown magnetic moment values 2.77 and 4.21 B.M respectively which are lower than the respective spin only values and indicate weak antiferromagnetic coupling interaction ${ }^{24}$ between the metal ions which further confirm the dinuclear nature of the complexes.

\section{Electronic spectra}

The $\mathrm{Cu}$ (II) complex of ligand $\mathrm{H}_{2} \mathrm{~L}$ exhibited a high intensity band at $380 \mathrm{~nm}$ in the UV-region. Appearance of this band is due to $\pi \rightarrow \pi^{*}$ transition associated with the azomethine linkage and ligand to metal charge transfer transition. ${ }^{22}$ The charge transfer may be from $p$-orbital of the phenolic oxygen to the vacant $d$-orbital of the $\mathrm{Cu}$ (II) ion. The electronic spectrum of $\mathrm{Cu}(\mathrm{II})$ complex showed three bands at $950 \mathrm{~nm}\left(\varepsilon=40 \mathrm{dm}^{3} \mathrm{~mol}^{-1} \mathrm{~cm}^{-1}\right), 685 \mathrm{~nm}(\varepsilon=$ $\left.54 \mathrm{dm}^{3} \mathrm{~mol}^{-1} \mathrm{~cm}^{-1}\right)$ and $540 \mathrm{~nm}\left(\varepsilon=44 \mathrm{dm}^{3} \mathrm{~mol}^{-1} \mathrm{~cm}^{-1}\right)$, these bands have been assigned to the transitions ${ }^{2} \mathrm{~B}_{1} \rightarrow$ ${ }^{2} \mathrm{~A}_{1}\left(v_{1}\right),{ }^{2} \mathrm{~B}_{1} \rightarrow{ }^{2} \mathrm{~B}_{2}\left(v_{2}\right)$ and ${ }^{2} \mathrm{~B}_{1} \rightarrow{ }^{2} \mathrm{E}\left(v_{3}\right)$ respectively. These transitions are characteristic of square pyramidal geometry. ${ }^{25}$ The band observed at $685 \mathrm{~nm}$ is indicative of $\mathrm{Cu}$ (II) d-d transition. ${ }^{26} \mathrm{Ni}$ (II) complex showed absorption bands at $980 \mathrm{~nm}\left(\varepsilon=30 \mathrm{dm}^{3} \mathrm{~mol}^{-1} \mathrm{~cm}^{-1}\right), 615 \mathrm{~nm}(\varepsilon=60$ $\left.\mathrm{dm}^{3} \mathrm{~mol}^{-1} \mathrm{~cm}^{-1}\right), 398 \mathrm{~nm}\left(\varepsilon=84 \mathrm{dm}^{3} \mathrm{~mol}^{-1} \mathrm{~cm}^{-1}\right)$ and these bands can be assigned to ${ }^{3} \mathrm{~A}_{2 \mathrm{~g}}(\mathrm{~F}) \rightarrow{ }^{3} \mathrm{~T}_{2 \mathrm{~g}}(\mathrm{~F})\left(v_{1}\right),{ }^{3} \mathrm{~A}_{2 \mathrm{~g}}(\mathrm{~F}) \rightarrow$ ${ }^{3} \mathrm{~T}_{1 \mathrm{~g}}(\mathrm{~F})\left(v_{2}\right)$ and ${ }^{3} \mathrm{~A}_{2 \mathrm{~g}}(\mathrm{~F}) \rightarrow{ }^{3} \mathrm{~T}_{1 \mathrm{~g}}(\mathrm{P})\left(v_{3}\right)$ transitions respectively suggesting octahedral geometry. ${ }^{27}$ The band around $980 \mathrm{~nm}$ is expected for the Nickel(II) d-d transition. ${ }^{26} \mathrm{Co}(\mathrm{II})$ complex displayed three bands at 905 $\left(\varepsilon=43 \mathrm{dm}^{3} \mathrm{~mol}^{-1} \mathrm{~cm}^{-1}\right), 585 \mathrm{~nm}\left(\varepsilon=52 \mathrm{dm}^{3} \mathrm{~mol}^{-1} \mathrm{~cm}^{-1}\right)$ and $503\left(\varepsilon=61 \mathrm{dm}^{3} \mathrm{~mol}^{-1} \mathrm{~cm}^{-1}\right)$ which can be assigned to the transitions ${ }^{4} \mathrm{~A}_{2}+{ }^{4} \mathrm{E} \rightarrow{ }^{4} \mathrm{~B}_{1},{ }^{4} \mathrm{~A}_{2}+{ }^{4} \mathrm{E} \rightarrow{ }^{4} \mathrm{E}(\mathrm{P})$ and ${ }^{4} \mathrm{~A}_{2}+{ }^{4} \mathrm{E} \rightarrow{ }^{4} \mathrm{~A}_{2}(\mathrm{P})$ respectively which are characteristic of square pyramidal geometry. ${ }^{27}$

\section{${ }^{1} H$ NMR spectra}

The ${ }^{1} \mathrm{H}$ NMR spectrum of ligand $\mathrm{H}_{2} \mathrm{~L}$ recorded in DMSO$d_{6}$ showed a peak at $\delta 2.09$ (s, $6,2 \times \mathrm{ArCH}_{3}$ ) due to methyl group at 4-position on the phenol rings. Four methylene protons have resonated at $\delta 3.61\left(\mathrm{~s}, 4,2 \times \mathrm{CH}_{2}\right)$ as a singlet and the four azomethine protons have resonated as a singlet at $\delta 8.51(\mathrm{~s}, 4,4 \times \mathrm{CH}=\mathrm{N}-)$ and protons due to the amide function have appeared as a singlet at $\delta 11.70$ (s, 4, $4 \times \mathrm{NH})$. Two protons due to phenolic $-\mathrm{OH}$ have appeared at $\delta 12.06(\mathrm{~s}, 1 \mathrm{H})$ as a singlet whereas the four aromatic protons have resonated at $\delta 7.23\left(\mathrm{~s}, 4,2 \times \mathrm{ArH}_{2}\right)$ as a singlet.
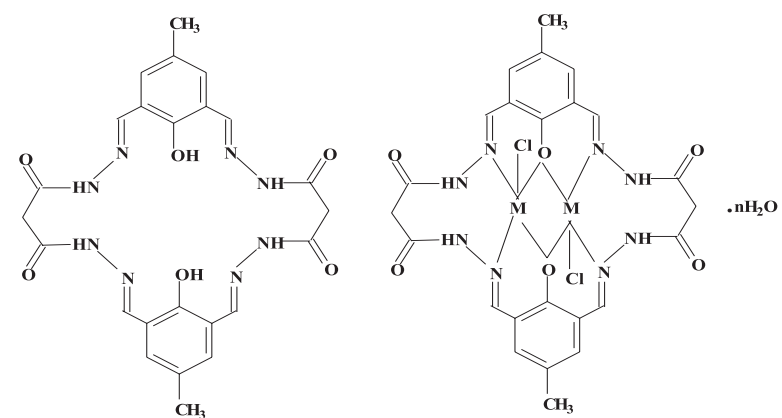

$$
\begin{aligned}
\mathrm{M}=\mathrm{Cu}(\mathrm{II}), \mathrm{Ni}(\mathrm{II}) \cdot \mathrm{H}_{2} \mathrm{O}, \mathrm{Co}(\mathrm{II}), \mathrm{Zn}(\mathrm{II}), \mathrm{Cd}(\mathrm{II}) \text { and } \mathrm{Hg}(\mathrm{II}) \\
\mathrm{n}=\mathbf{1 - 3}
\end{aligned}
$$

Figure 1. Structures of the ligand $\mathrm{H}_{2} \mathrm{~L}$ and its complexes. 
The ${ }^{1} \mathrm{H}$ NMR spectrum of $\mathrm{Cd}(\mathrm{II})$ complex of ligand $\mathrm{H}_{2} \mathrm{~L}$ scanned in DMSO- $d_{6}$ showed a peak at $\delta 2.24$ (s, 6, $2 \times \mathrm{ArCH}_{3}$ ) due to six methyl protons at 4-position of phenyl rings. Four methylene protons have resonated at $\delta 3.61$ (s, $4,2 \times \mathrm{CH}_{2}$ ) and four aromatic protons of the phenyl ring have resonated as a singlet at $\delta 7.58\left(\mathrm{~s}, 4,2 \times \mathrm{ArH}_{2}\right)$ respectively. Four azomethine protons have appeared at $\delta$ $8.47(\mathrm{~s}, 4, \mathrm{CH}=\mathrm{N}-)$ as a singlet. The signal observed at $\delta$ 12.06 due to the protons of phenolic -OH group, in case of ligand has disappeared indicating coordination of the phenoxide ions to the metal ions via deprotonation. ${ }^{15}$ Four - $\mathrm{NH}$ protons of amide function have resonated at $\delta 11.65$ (s, $4,4 \mathrm{xNH})$ as a singlet. These observations reveal that the involvement of phenolic $-\mathrm{OH}$ groups in the complexation with the metal ions via deprotonation indicated by the disappearance of the signals due to $-\mathrm{OH}$ groups in the $\mathrm{Cd}$ (II) complex. Further, the changes in the chemical shifts of azomethine function and aromatic protons in the $\mathrm{Cd}(\mathrm{II})$ complex suggest coordination of the azomethine nitrogen with metal ions.

\section{ESR spectrum of $\mathrm{Cu}(\mathrm{II})$ complex}

The X-band ESR spectrum of the powder $\mathrm{Cu}$ (II) complex (Figure 2) was recorded at room temperature using DPPH as a reference standard. The spectrum appeared to be slightly broadened with $\mathrm{g}_{\perp}=2.08$ and $\mathrm{g}_{\|}=2.17$. Generally, chlorobridged binuclear $\mathrm{Cu}$ (II) complexes give broad ESR signals. ${ }^{22}$ The observed ESR spectrum is characteristic of square pyramidal geometry. ' $\mathrm{g}$ ' values averaged to overall directions and ' $G$ ' which is a measure of extent of exchange interaction between the metal ions have been calculated using the relations $\mathrm{g}_{\mathrm{av}}^{2}=1 / 3\left(2 \mathrm{~g}_{\perp+}^{2} \mathrm{~g}_{\|}^{2}\right)$ and $\mathrm{G}=\left(\mathrm{g}_{\|}-2\right) /\left(\mathrm{g}_{\perp}-2\right)$. By observing the $\mathrm{g}$-values it is clear that $\mathrm{g}_{\mathrm{e}}<\mathrm{g}_{\perp}<\mathrm{g}_{\|}(2.0023<$
$2.0844<2.1719)$ ) which suggest that $\mathrm{d}_{\mathrm{x} 2-\mathrm{y} 2}$ orbital is in the ground state and the $\mathrm{d}^{9}$ configuration is $\left(\mathrm{e}_{\mathrm{g}}\right)^{4}\left(\mathrm{a}_{\mathrm{lg}}\right)^{2}\left(\mathrm{~b}_{2 \mathrm{~g}}\right)^{2}\left(\mathrm{~b}_{1 \mathrm{~g}}\right)^{1}$. The ' $\mathrm{g}$ ' values are related to the axial symmetry ${ }^{22}$ and $g_{||}>g_{\perp}$ suggests square pyramidal geometry for $\mathrm{Cu}$ (II) complex..$^{27} \mathrm{In}$ the present case the value of ' $G$ ' was found to be 2.03 . According to Hathaway, ${ }^{28}$ if $\mathrm{G}$ value is greater than 4 , the exchange interaction is negligible whereas $G$ value less than 4 indicates considerable exchange interaction between metal ions in the solid complex. In the present case $\mathrm{G}=2.03$ indicate considerable exchange interaction between the $\mathrm{Cu}$ (II) ions in the complex which further supports the dinuclear nature of the complexes.
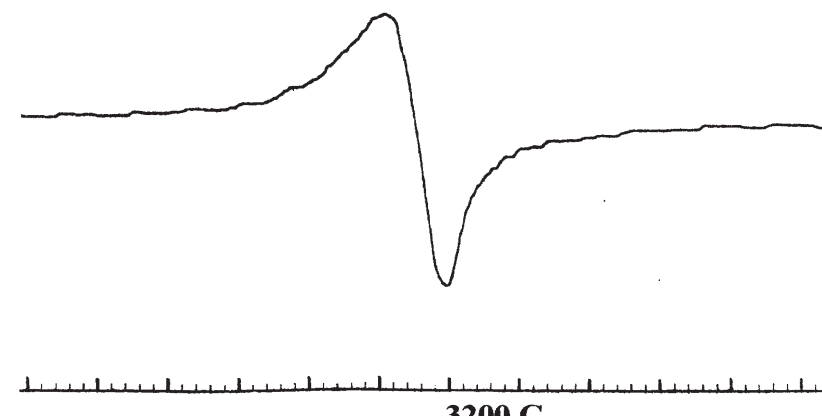

Figure 2. ESR spectrum of the $\mathrm{Cu}(\mathrm{II})$ complex.

\section{FAB mass spectrum of $\mathrm{Cu}(\mathrm{II})$-complex of ligand $\mathrm{H}_{2} \mathrm{~L}$}

FAB mass spectrum of $\mathrm{Cu}(\mathrm{II})$-complex of ligand $\mathrm{H}_{2} \mathrm{~L}$ has been depicted in Figure 3. The spectrum showed a molecular ion peak $\mathbf{M}^{+}$at $m / z, 770$, which is equivalent to its molecular weight. The molecular ion by the loss of four hydrogen radicals gave a fragment ion peak $\mathrm{A}_{1}$ at $\mathrm{m} / \mathrm{z} 766$. The fragment ion $\mathrm{A}_{1}$ by the loss of three water molecules, two chloride and two methyl radicals simultaneously gave

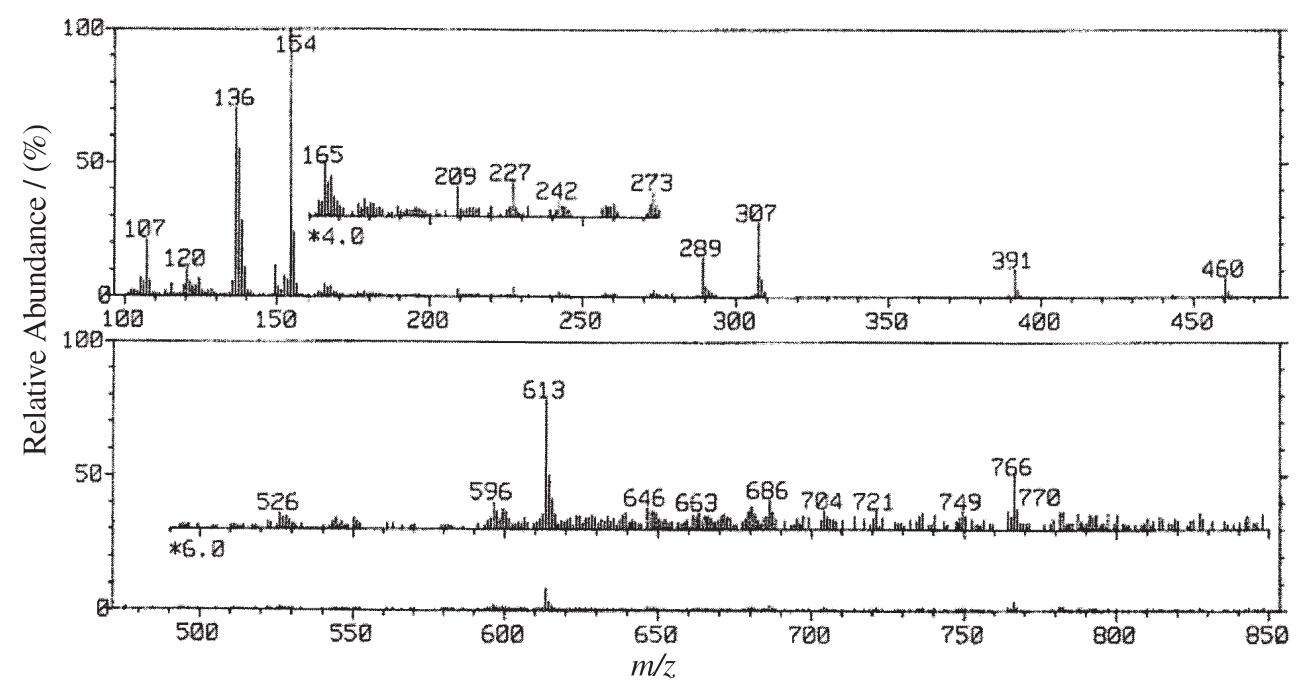

Figure 3. FAB mass spectrum of the $\mathrm{Cu}(\mathrm{II})$ complex. 
a fragment ion $\mathrm{A}_{2}$, at $m / z 612$. This fragment ion $\mathrm{A}_{2}$ by the expulsion of $\mathrm{C}_{5} \mathrm{H}_{4} \mathrm{~N}_{4} \mathrm{O}_{2}$ species gave another fragment ion $\mathrm{A}_{3}$ at $m / 2,460$. Further, the fragment ion $\mathrm{A}_{3}$ by the loss of $\mathrm{C}_{3} \mathrm{O}_{2}$ species gave a fragment ion $\mathrm{A}_{4}$ at $\mathrm{m} / \mathrm{z} 391$. Finally, the fragment ion $\mathrm{A}_{4}$ by the loss of $\mathrm{C}_{7} \mathrm{H}_{4} \mathrm{NO}$ species gave a fragment ion $\mathrm{A}_{5}$ at $\mathrm{m} / z 2$ 273. The fragmentation pattern is given in Scheme 1. It clearly indicates dinuclear nature of the complex and two $\mathrm{Cu}$ (II) ions are held in the macrocyclic compartment of the ligand $\mathrm{H}_{2} \mathrm{~L}$. The metal ions are bonded to two phenoxo bridges which endogenously coordinate to the metal ions and the other coordinating sites in the ligand are the azomethine nitrogen atoms. Both phenoxide and azomethine groups surround the two metal ions which are in close proximity within the ligand molecule to form a square base. A chloride ion coordinates to each metal ion from opposite sides to give square pyramidal configuration to the metal ions. The FAB mass spectrum confirms the dinuclear nature of the metal complex.

\section{Biological activity}

The ligand $\mathrm{H}_{2} \mathrm{~L}$ and its $\mathrm{Cu}$ (II), $\mathrm{Ni}(\mathrm{II}), \mathrm{Co}(\mathrm{II})$ and $\mathrm{Zn}$ (II) complexes were tested for their antibacterial and antifungal activity. The zones of inhibitions of the antimicrobial activity have been presented in the Table 4 . The results of the antibacterial activity of the ligand $\mathrm{H}_{2} \mathrm{~L}$ and its $\mathrm{Cu}(\mathrm{II})$, $\mathrm{Ni}(\mathrm{II}), \mathrm{Co}(\mathrm{II})$ and $\mathrm{Zn}$ (II) complexes revealed that the ligand as well as its $\mathrm{Cu}(\mathrm{II}), \mathrm{Ni}$ (II), $\mathrm{Co}$ (II) and $\mathrm{Zn}$ (II) complexes displayed very weak activity against both the bacteria $E$. coli and $S$. aureus with 12-14 mm inhibition compared to the standard drug ciprofloxacin which showed $24 \mathrm{~mm}$ and $22 \mathrm{~mm}$ inhibition against E.coli and S. aureus respectively.

The antifungal activity results of the ligand $\mathrm{H}_{2} \mathrm{~L}$ and its complexes revealed that the ligand showed less activity against A.Niger and good activity against F.oxysporum with $14 \mathrm{~mm}$ and $18 \mathrm{~mm}$ inhibition respectively, compared to the standard drug griseofulvin with $24 \mathrm{~mm}$ and $23 \mathrm{~mm}$ inhibition. $\mathrm{Cu}(\mathrm{II}), \mathrm{Ni}(\mathrm{II}), \mathrm{Co}(\mathrm{II})$ and $\mathrm{Zn}$ (II) complexes were found to be less active with $10-15 \mathrm{~mm}$ inhibition against
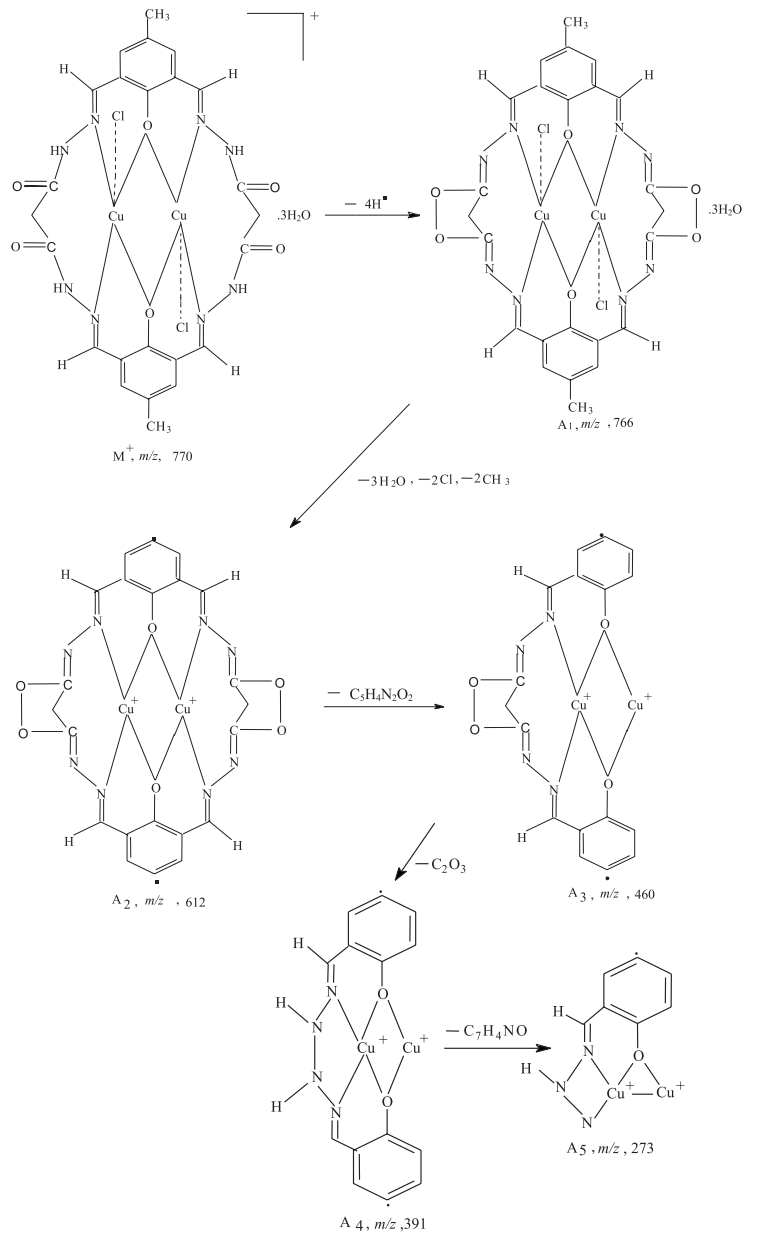

Scheme 1. FAB mass fragmentation pattern of the $\mathrm{Cu}(\mathrm{II})$ complex.

Table 3. FAB mass spectral data of the $\mathrm{Cu}(\mathrm{II})$ complex

\begin{tabular}{lclc}
\hline Complex & $m / z$ & Peak assignments & $\begin{array}{c}\text { Relative \% } \\
\text { abundance }\end{array}$ \\
\hline$\left[\mathrm{Cu}_{2}(\mathrm{~L}) \mathrm{Cl}_{2}\right] .3 \mathrm{H}_{2} \mathrm{O}$ & 770 & $\left\{\left[\mathrm{Cu}_{2}(\mathrm{~L}) \mathrm{Cl}_{2}\right] .3 \mathrm{H}_{2} \mathrm{O}\right\}^{+}$ & 3 \\
& 766 & {$\left[\mathrm{Cu}_{2}\left(\mathrm{C}_{22} \mathrm{H}_{12} \mathrm{~N}_{8} \mathrm{O}_{6}\right) \mathrm{Cl}_{2}\right]^{+}$} & 5 \\
& 612 & {$\left[\mathrm{Cu}_{2}\left(\mathrm{C}_{22} \mathrm{H}_{12} \mathrm{~N}_{8} \mathrm{O}_{6}\right)\right]^{+}$} & 12 \\
& 460 & {$\left[\mathrm{Cu}_{2}\left(\mathrm{C}_{17} \mathrm{H}_{8} \mathrm{~N}_{4} \mathrm{O}_{4}\right)\right]^{+}$} & 10 \\
& 391 & {$\left[\mathrm{Cu}_{2}\left(\mathrm{C}_{14} \mathrm{H}_{8} \mathrm{~N}_{4} \mathrm{O}_{2}\right)\right]^{+}$} & 12 \\
& 273 & {$\left[\mathrm{Cu}_{2}\left(\mathrm{C}_{7} \mathrm{H}_{4} \mathrm{~N}_{3} \mathrm{O}\right)\right]^{+}$} & 2 \\
\hline
\end{tabular}

Table 4. Antibacterial and antifungal activities of the ligand $\mathrm{H}_{2} \mathrm{~L}$ and its complexes

\begin{tabular}{|c|c|c|c|c|}
\hline \multirow[t]{2}{*}{ Test Compound } & \multicolumn{2}{|c|}{ Antibacterial activity(zone of inhibition in $\mathrm{mm}$ ) } & \multicolumn{2}{|c|}{ Antifungal activity(zone of inhibition in $\mathrm{mm}$ ) } \\
\hline & E. coli & S. aureus & A. niger & F. oxysporum \\
\hline (Ligand) $\mathrm{H}_{2} \mathrm{~L}$ & 12 & 12 & 14 & 18 \\
\hline $\mathrm{Cu}$-complex & 13 & 11 & 15 & 14 \\
\hline $\mathrm{Ni}$ - complex & 12 & 14 & 14 & 12 \\
\hline Co- complex & 12 & 12 & 14 & 15 \\
\hline Zn- complex & 12 & 13 & 10 & 13 \\
\hline Ciprofloxacin & 24 & 22 & - & - \\
\hline Griseofulvin & - & - & 24 & 23 \\
\hline DMF* (Control) & 0 & 0 & 0 & 0 \\
\hline
\end{tabular}

* Freshly distilled DMF. 
A.niger and F.oxysporum respectively compared to the standard drug.

A comparative study of the ligand and its complexes indicates that some of the metal chelates exhibit higher antimicrobial activity than the free ligand. The increase in the antimicrobial activity of metal chelates is due to the presence of metal ions in the complexes.

\section{Conclusions}

The ligand $N, N$-bis(2,6-diiminomethyl-4-methyl-1hydroxylphenyl)malonoyl dicarboxamide behaved as a binegative octadentate chelating agent coordinating through two deprotonated phenoxo groups and four azomethine nitrogen atoms. The ligand was so designed that it can secure two metal ions in the close proximity. Analytical data, electronic spectra, magnetic susceptibility, IR, ${ }^{1} \mathrm{H}$ NMR, ESR, FAB mass spectral data reveal dinuclear nature of all the complexes. The dinuclear nature of the complexes was confirmed on the basis of ESR and FAB mass spectral data, it is further confirmed on the basis of considerable low value of magnetic moments in the case of $\mathrm{Cu}(\mathrm{II}), \mathrm{Ni}(\mathrm{II})$, and $\mathrm{Co}(\mathrm{II})$ complexes, which indicate antiferromagnetic coupling interaction between the two metal centers in the complexes. The ligand and its $\mathrm{Cu}(\mathrm{II})$, $\mathrm{Ni}(\mathrm{II}), \mathrm{Co}(\mathrm{II})$ and $\mathrm{Zn}(\mathrm{II})$ complexes were tested for antimicrobial activity and the compounds were found to be less active against the bacteria E.coli and S.aureus and the fungi A.niger and Foxysporum, but the ligand alone was found to be active against the fungus F.oxysporum.

\section{Acknowledgements}

The authors thank the Chairman, Department of Chemistry, Gulbarga University, Gulbarga for providing the facilities. They also thank SIF, IISc Bangalore, CDRI, Lucknow for providing NMR, ESR and FAB mass spectral data. One of the authors (O.B.I.) thanks Gulbarga University, Gulbarga for providing a research fellowship.

\section{References}

1. Fenton, D. E. In Advances in Inorganic and Bioorganic Mechanisms; Sykes, A. G., ed.; Academic: London, 1983, vol. 12B, p. 187.

2. Fenton, D. E.; Casellato, U.; Vigato, P.A.; Vidali, M.; Inorg. Chim. Acta 1984, 95, 187.

3. Zanello P.; Tamburini S.; Vigato P.A.; Mazzocchin, G. A.; Coord. Chem. Rev. 1987, 77, 165.

4. Lehn, J. M.; Pure Appl. Chem. 1978, 50, 871.
5. Fenton D.E.; Okawa, H.; Perspectives on Bioinorganic Chemistry, JAI Press: London, 1993, p. 8.

6. Karthikeyan, S.; Rajendiran, T.M.; Kannappan, R.; Mahalakshmy, R.; Venkateshan,R.; Sambasiva Rao, P.; Proc. Indian Acad. Sci. (Chem. Sci.) 2001, 113, 245.

7. Casellato, U.; Vigato P.A.; Vidali, M.; Coord. Chem. Rev. 1977, 23,31 .

8. Pilkington, N. H.; Robson, R.; Aust. J. Chem. 1970, 23, 2225.

9. Okawa, H.; Kida, S.; Bull. Chem. Soc. Japan 1972, 5, 1759.

10. Ullas Shetty, N.; Revankar, V.K.; Mahale, V. B.; Proc. Indian Acd. Sci., (Chem. Sci.) 1997, 109, 7.

11. Brian, S.F.; Hannaford, A.J.; Smith, P.W.G.; Tatchell A.R.; Vogel's Text Book of Partical Organic Chemistry, ELBS Publishers: Singapore, 1989, p. 395.

12. Denton D. A.; Suschitzky, H.; J. Chem. Soc. 1963, 4741.

13. Sangapure, S.S.; Raga B.V.; Asian J. Chem. 1997, 9, 663.

14. Geary, W.J.; Coord. Chem. Rev. 1972, 1, 81.

15. Malhotra, R; Sudhir, K.; Jyoti; Singal, H. R.; Dhindra, K. S.; Indian J. Chem. 2000, 39A, 421.

16. Singh N.K.; Singh S.B.; Indian J. Chem. 2001, 40A, 1047.

17. Warad, D.U.; Satish, C.D.; Kulkarni, V.H.; Bajgur, C.S.; Indian J. Chem. 2000, 39A, 418.

18. Sashidhara, G. M.; Goudar, T.R.; J. Indian Chem. Soc. 2001, $78,360$.

19. Srinivas, B.; Arulsamy, N.; Zacharias, P. S.; Polyhedron 1991, 10, 731 .

20. Choudhary, C. K.; Choudhary, R.K.; Mishra, L. K.; J. Indian Chem. Soc. 2003, 80, 693.

21. Mohapatra, B.B.; Saraf, S.K.; J. Indian.Chem. Soc. 2003, 80, 696.

22. Annigeri, S.M.; Naik, A.D.; Gangadharmath,U. B.; Revankar,V.K; Mahale,V.B.; Trans. Met .Chem. 2002, 27, 316.

23. Kannappan, R.; Mahalakshmy, R.; Rajendiran, T.M.; Venkateshan, R.; Sambashiva Rao, P.; Proc. Indian Acad. Sci. (Chem. Sci.) 2003, 115, 1.

24. Naik, A.D.; Annigeri, S.M.; Gangadharmath,U. B.; Revankar,V.K.; Mahale,V.B.; Reddy,V.; Indian J. Chem. 2002, 41A, 2046.

25. Sengottuvelan, N.; Manonmani, J.; Kandaswamy, M.; Polyhedron 2002, 21, 2767.

26. Koji, A.; Matsfuji, K.; Ohba, M.; Okawa, H.; Inorg. Chem. 2002, 41, 4461.

27. Satyanarayana, D.N.; Electronic Absorption Spectroscopy and Related Techniques, Universities Press: Hyderabad, 2001.

28. Hathaway, B.J.; Billing, D.E.; Coord. Chem. Rev. 1970, 6, 143.

Received: June 25, 2004 Published on the web: May 25, 2005 